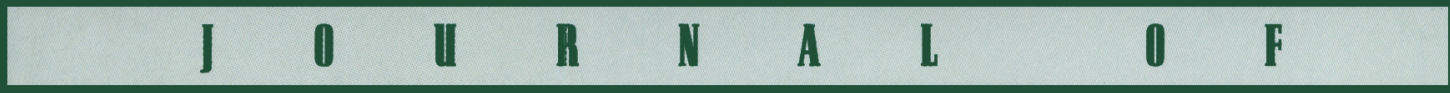

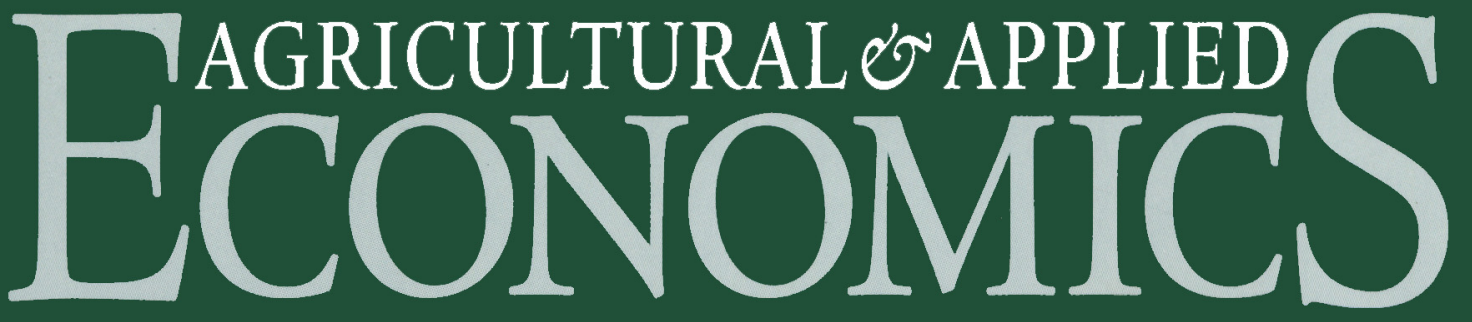

\title{
VOLUME 38
}

\section{August 2006}

NUMBER 2

\section{Articles}

\section{Lifetime Achievement Awards}

The Future of Agricultural Economics in Extension / Stephen H. Amosson

My Career Path and Guiding Principles / Gerald A. Doeksen

To Remain Relevant, Change Agents Also Need to Change / Danny A. Klinefelter

Price Endogenous Mathematical Programming Models and Trade Analysis / Thomas H. Spreen

Lifetime Achievement Award-Comments / Abner Womack

\section{Presidential Address}

The Environment for Scholarship in Agricultural Economies Extension/Damona Doye

\section{Invited Paper Sessions}

Demand for Urban Forests and Economic Welfare: Evidence from the Southeastern U.S. Cities / Pengyu Zhu and Yaoai Zhang

\section{Presidential Address}

The Environment for Scholarship in Agricultural Economies Extension / Damona Doye

\section{Invited Paper Sessions}

Demand for Urban Forests and Economic Welfare: Evidence from the Southeastern U.S. Cities / Pengyu Zhu and Yaogi Zhang

Estimating Effects of an Urban Growth Boundary on Land Development / Seong-Hoon Cho, Zhuo Chen, Steven T. Yen; and David B. Eastwood

Two Dimensions of the Spatial Distribution of Housing: Dependency and Heterogeneity across Tennessee's Six Metropolitan Statistical Areas / Seong-Hoon Cho, Christopher D. Clark and William M. Park

Wilderness and Primitive Area Recreation Participation and Consumption: An Examination of Demographic and Spatial Factors / J.M. Bowker, D. Murphy, H.K. Cordell, D.B.K. English, J.C. Bergstrom, C.M. Starbuck, C.J. Betz, G.T. Green

Animal Disease Pre-event Preparedness versus Post-event Response: When Is It Economic to Protect? / Levan Elbakidze and Bruce A. McCarl

Invasive Species and Biosecurity: Cost of Monitoring and Controlling Mediterranean Fruit Flies in Florida / Raphael Pierre, Thomas H. Spreen, and Charles B. Moss

Discussion of Biosecurity, Diseases, and Invasive Species: Implications of Bioterrorism for Agriculture: Discussion / Edward A. Evans

Biosecurity, Diseases, and Invasive Species: Implications of Bioterrorism for Agriculture: Discussion / William F. Hahn

An Outlook for the Biofuels Industry in the Southern U.S. / Anthony Crooks and John Dunn

Challenges to Producer Ownership of Ethanol and Biodiesel Production Facilities / Phil Kenkel, Rodney B. Holcomb

Economic Impacts of Biofuel Production on States and Rural Communities / Joe L. Parcell and Patrick Westhoff

Economic Competitiveness of Bioenergy Production and Impacts on the Southern Region's Agriculture/Burton C. English,

Daniel G. De La Torre Ugarte, Marie E. Walsh, Chad Hellwinkel, and Jamey Menard

Economic Returns to Entrepreneurial Behavior/R. Brent Ross and Randall E. Westgren

Collective Entrepreneurship: An Emerging Phenomenon in Producer-Owned Organizations / Michael L. Cook, Brad Plunkett

Can Entrepreneurship Be Taught? / Peter G. Klein and J. Bruce Bullock

Putting Entrepreneurship into Agricultural Economics: Research and Teaching Perspectives-Discussion / Vincent Amanor-Boadu

Keynote Address-Southern Agricultural Economics Association, Orlando, FL, February 2006

The Coming Tug-Of-War: Forces Moving the 2007 Farm Bill / Robert E. Young II

Abstracts

Selected Papers

Organized Symposia

Selected Posters

Secretany-Treastirer"'s Rapartp 


\title{
EDITORIAL STAFF
}

\author{
Editor \\ Henry Kinnucan \\ Auburn University \\ Associate Editors \\ Dragan Miljkovic \\ North Dakota State University \\ Øystein Myrland \\ University of Tromsø, Norway
}

Editorial Council

\author{
Darrell J. Bosch \\ Virginia Tech \\ David L. Debertin \\ University of Kentucky \\ Mark Denbaly \\ Economist, USDA, ERS \\ Kevin C. Dhuyvetter \\ Kansas State University \\ Shenggen Fan \\ International Food Policy \\ Research Institute \\ Diane Hite \\ Auburn University \\ Michael M. Hudson \\ Mississippi State University \\ Scott H. Irwin \\ University of Illinois
}

\author{
P. Lynn Kennedy \\ Louisiana State University \\ Carl Johan Lagerkvist \\ International Food Policy \\ Research Institute \\ Andrew M. McKenzie \\ University of Arkansas \\ Daniel V. Rainey \\ University of Arkansas \\ Daryll E. Ray \\ University of Tennessee \\ Cathy A. Roheim \\ University of Rhode Island \\ Loren W. Tauer \\ Cornell University
}

\section{EDITORIAL POLICY}

The Journal of Agricultural and Applied Economics (JAAE) provides a forum for creative and scholarly work in agricultural economics and related areas. Contributions on methodology and applications in business, extension, research, and teaching phases of agricultural and applied economics are equally encouraged. Submitted manuscripts are subject to peer review for publication consideration. Submission of critiques or comments on JAAE articles are welcomed.

\section{EDITORIAL COMMUNICATIONS}

The editorship of the $J A A E$ will change with Volume 37. Please send all manuscript submissions and editorial correspondence for manuscripts submitted after June 30, 2004 to Henry W. Kinnucan, Editor, JAAE, Department of Agricultural Economics and Rural Sociology, 213 Comer Hall, Simmons Drive, Auburn University, Auburn, AL 36849-5401. Phone: (334) 844-5614; Fax: (334) 844-5639; Email: JAAE@auburn.edu.

The Journal of Agricultural and Applied Economics (ISSN 1074-0708) is published in April, August, and December by the Southern Agricultural Economics Association (SAEA). Visit our worldwide web site at http://www.agecon.uga.edu/ jaae/jaae.htm.

Copyright (C) 2006 by the Southern Agricultural Economics Association. Any article or other material published in the $J A A E$ may not be resubmitted for publication or republished elsewhere in full or in part without the written permission of the editor. 


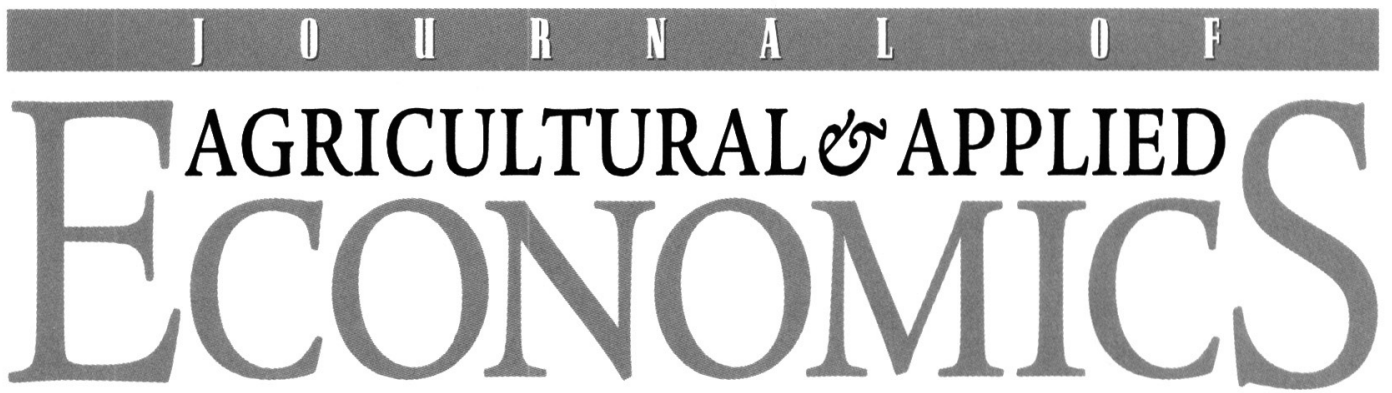

\begin{tabular}{lll}
\hline VOLIIME 38 & AllGIIST 20106 & NIIMBER 2 \\
\hline
\end{tabular}

\section{Lifetime Achievement Awards}

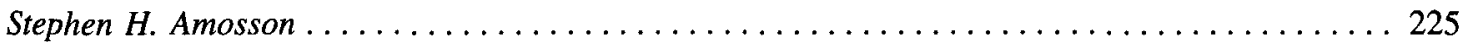

The Future of Agricultural Economics in Extension / Stephen H. Amosson . . . . . . . . . . . 229

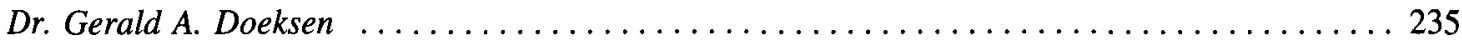

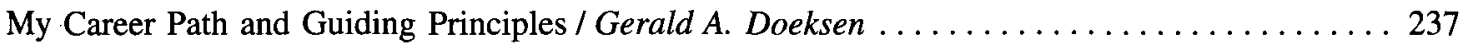

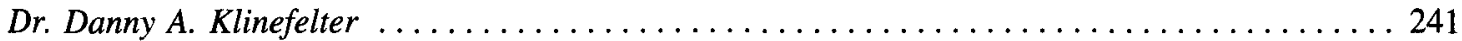

To Remain Relevant, Change Agents Also Need to Change / Danny A. Klinefelter . . . . . . . . 243

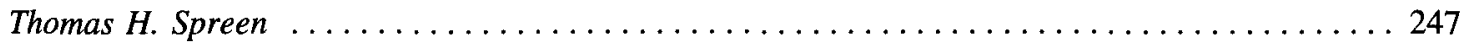

Price Endogenous Mathematical Programming Models and Trade Analysis / Thomas H. Spreen .. 249

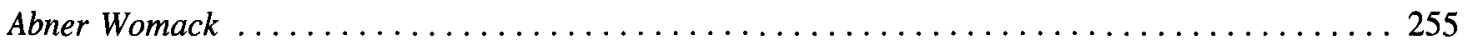

Lifetime Achievement Award-Comments / Abner Womack ................... 257

\section{Presidential Address}

Damona Doye ............................................. 259

The Environment for Scholarship in Agricultural Economics Extension / Damona Doye ...... 261

\section{Invited Paper Sessions}

Demand for Urban Forests and Economic Welfare: Evidence from the Southeastern U.S. Cities /

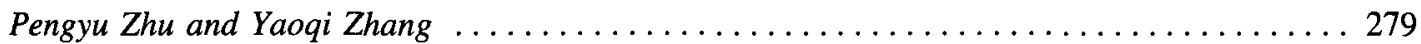

Estimating Effects of an Urban Growth Boundary on Land Development / Seong-Hoon Cho,

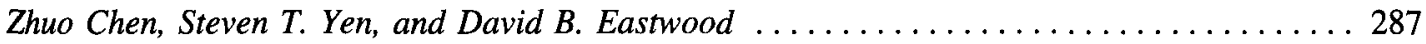

Two Dimensions of the Spatial Distribution of Housing: Dependency and Heterogeneity across Tennessee's Six Metropolitan Statistical Areas / Seong-Hoon Cho, Christopher D. Clark, and William M. Park . . . . . . . . . . . . . . . . . . . . . . . . . . . . . . . . . . 299

Wilderness and Primitive Area Recreation Participation and Consumption: An Examination of Demographic and Spatial Factors / J.M. Bowker, D. Murphy, H.K. Cordell, D.B.K. English,

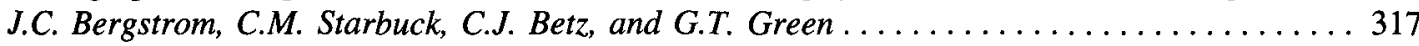

Animal Disease Pre-Event Preparedness versus Post-Event Response: When Is It Economic to Protect? / Levan Elbakidze and Bruce A. McCarl . . . . . . . . . . . . . . . . . . . . . 327 
Invasive Species and Biosecurity: Cost of Monitoring and Controlling Mediterranean Fruit Flies in Florida / Raphael Pierre, Thomas H. Spreen, and Charles B. Moss

Discussion of Biosecurity, Diseases, and Invasive Species: Implications of Bioterrorism for Agriculture / Edward A. Evans

Biosecurity, Diseases, and Invasive Species: Implications of Bioterrorism for Agriculture:

Discussion of Elbakidze and McCarl and Pierre, Spreen, and Moss / William F. Hahn

An Outlook for the Biofuels Industry in the Southern United States / Anthony Crooks and John Dunn

Challenges to Producer Ownership of Ethanol and Biodiesel Production Facilities / Phil Kenkel, Rodney B. Holcomb . . . . . . . . . . . . . . . . . . . . . . . . . . . . . . . . 369

Economic Effects of Biofuel Production on States and Rural Communities / Joe L. Parcell and Patrick Westhoff .

Economic Competitiveness of Bioenergy Production and Effects on Agriculture of the Southern Region / Burton C. English, Daniel G. De La Torre Ugarte, Marie E. Walsh,

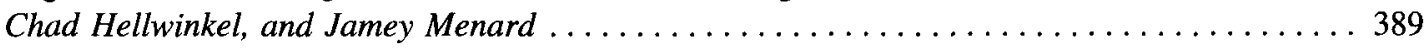

Economic Returns to Entrepreneurial Behavior/R. Brent Ross and Randall E. Westgren ..... 403

Collective Entrepreneurship: An Emerging Phenomenon in Producer-Owned Organizations /

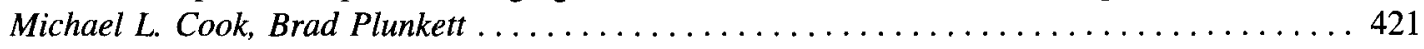

Can Entrepreneurship Be Taught? / Peter G. Klein and J. Bruce Bullock . . . . . . . . .. 429

Putting Entrepreneurship into Agricultural Economics: Research and Teaching Perspectives-

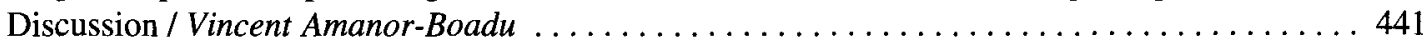

\title{
Keynote Address-Southern Agricultural Economics Association, Orlando, FL, February 2006
}

The Coming Tug-Of-War: Forces Moving the 2007 Farm Bill / Robert E. Young II . . . . .. 445

\begin{abstract}
s
Selected Papers $\ldots \ldots \ldots \ldots \ldots \ldots \ldots \ldots \ldots \ldots \ldots \ldots \ldots \ldots \ldots \ldots \ldots \ldots \ldots \ldots \ldots$

Organized Symposia Abstracts $\ldots \ldots \ldots \ldots \ldots \ldots \ldots \ldots \ldots \ldots \ldots \ldots \ldots \ldots \ldots \ldots \ldots$

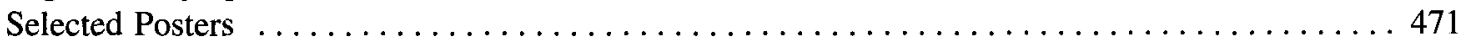

\section{SAEA Business}

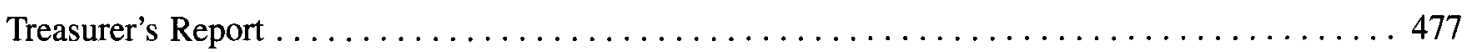

Editor's Report $\ldots \ldots \ldots \ldots \ldots \ldots \ldots \ldots \ldots \ldots \ldots \ldots \ldots \ldots \ldots \ldots \ldots \ldots \ldots \ldots \ldots$

SAEA Award Recipients

(1987-2005) 